\title{
Penggunaan Aplikasi Sayang ke Buah Hati (SEHATI) terhadap Asupan Zat Gizi Anak dan Pengetahuan Ibu Menerapkan Konsumsi Aneka Ragam Makanan Gizi Seimbang pada Anak Sekolah Dasar
}

\author{
Giyawati Yulilania Okinarum, ${ }^{1}$ Irvan Afriandi, ${ }^{2}$ Dida Akhmad Gurnida, ${ }^{3}$ \\ Herry Herman, ${ }^{4}$ Herry Garna, ${ }^{3}$ Tono Djuwantono ${ }^{6}$ \\ ${ }^{1}$ Alumnus Program Studi Magister Kebidanan, ${ }^{2}$ Departemen Ilmu Kesehatan Masyarakat, \\ ${ }^{3}$ Departemen Ilmu Kesehatan Anak, ${ }^{4}$ Departemen Orthopaedi dan Traumatologi, \\ ${ }^{5}$ Departemen Obstetri dan Ginekologi, Fakultas Kedokteran, Universitas Padjadjaran, Bandung, Indonesia
}

\begin{abstract}
Abstrak
Kesehatan dan gizi yang buruk pada anak usia sekolah dapat menghambat pertumbuhan fisik, perkembangan, dan kecerdasan. Konsumsi pangan masyarakat Indonesia belum sesuai dengan pesan gizi seimbang. Aplikasi Sayang ke Buah Hati (SEHATI) diharapkan dapat menjadi alat strategi promosi kesehatan untuk meningkatkan asupan zat gizi anak dan pengetahuan ibu menerapkan konsumsi aneka ragam makanan gizi seimbang. Tujuan penelitian ini menganalisis perbedaan asupan zat gizi anak dan pengetahuan ibu menerapkan konsumsi aneka ragam makanan gizi seimbang pada anak sekolah dasar sebelum dengan sesudah diterapkan aplikasi SEHATI. Periode penelitian 2-18 Maret 2017 di SDIT Jabal Nur Yogyakarta. Subjek adalah ibu yang memiliki anak usia sekolah dasar (8-12 tahun) dan anaknya yang memenuhi kriteria penelitian. Penelitian ini merupakan randomized controlled trial (RCT). Pengambilan sampel dilakukan secara acak. Kelompok intervensi mendapatkan pemasangan aplikasi SEHATI dan kontrol diberikan pendidikan kesehatan, tiap-tiap kelompok terdiri atas 30 responden. Data diolah dengan uji nonparametrik, yaitu uji t berpasangan pada data yang berdistribusi normal dan uji Mann-Whitney pada data yang tidak berdistribusi normal. Terdapat perbedaan bermakna penggunaan aplikasi SEHATI terhadap peningkatan pengetahuan ibu pada kelompok intervensi (25,9\%; $\mathrm{p} \leq 0,001)$, terjadi peningkatan skor asupan zat gizi anak pada kelompok intervensi yang bermakna, yaitu karbohidrat (13,8\%; $\mathrm{p}=0,038)$ dan vitamin $\mathrm{A}(51,5 \%$; $\mathrm{p}=0,005)$. Simpulan, terdapat perbedaan peningkatan asupan zat gizi dan pengetahuan ibu menerapkan konsumsi aneka ragam makanan gizi seimbang pada anak sekolah dasar sebelum dengan sesudah penggunaan aplikasi SEHATI.
\end{abstract}

Kata kunci: Aplikasi SEHATI, asupan zat gizi, konsumsi aneka ragam makanan, pengetahuan

\section{Sayang ke Buah Hati (SEHATI) Application Usage on Children Nutrient Intake and Mothers' Knowledge in Implementing Nutritionally Balanced Food Variety among Primary School Children}

\begin{abstract}
Nutrient imbalance affects children growth and development. Sayang ke Buah Hati (SEHATI) was an application developed for health promotion strategies to increase children nutrient intake and mothers' knowledge in implementing consumption on nutritionally balanced food variety. The purpose of this study was to analyze the differences of children nutrient intake and mothers' knowledge in implementing consumption of a variety of nutritionally balanced food on primary school children before and after applying the SEHATI application. Subjects were 30 randomly selected mothers who have primary school age children (8-12 years) and their children. This study is a randomized controlled trial (RCT) conducted on 2-18 of March 2017 in SDIT Jabal Nur Yogyakarta. The intervention group got the SEHATI application installed and health education. The data collected is processed by the paired test on normally distributed data and Mann Whitney tests on data that are not normally distributed. Results showed significant increased knowledge of mothers in the intervention group significantly $(25.9 \%, \mathrm{p} \leq 0.001)$. Increased nutrients scores of children in the intervention group were carbohydrates $(13.8 \%, \mathrm{p}=0.038)$ and vitamin $\mathrm{A}(51.5 \%, \mathrm{p}=0.005)$. In conclusions, there are differences of child nutrient intake and mothers' knowledge in implementing consumption of a variety of nutritionally balanced food in primary school children before and after SEHATI application usage.
\end{abstract}

Key words: Knowledge, nutrient intake, nutritionally balanced food, SEHATI application

Received: 28 May 2017; Revised: 29 August 2017; Accepted: 20 November 2017; Published: 27 December 2017

Korespondensi: Giyawati Yulilania Okinarum, S.S.T., M.Keb. Program Studi Magister Kebidanan, Fakultas Kedokteran, Universitas Padjadjaran, Jln. Professor Eyckman No. 38, Bandung 40161, Jawa Barat, Indonesia. Telepon: (022) 2032170. HP: o82210237139; 085729348555. E-mail: gitaajib@gmail.com 


\section{Pendahuluan}

Pola makan merupakan perilaku paling penting yang dapat memengaruhi keadaan gizi anak. Hal ini disebabkan oleh kuantitas dan kualitas makanan serta minuman yang dikonsumsi akan memengaruhi tingkat kesehatan seorang anak. Pola makan yang buruk yang dikombinasi dengan perilaku tidak sehat seperti gaya hidup sedentary, berkontribusi terhadap kejadian overweight dan obesitas bukan hanya pada orang dewasa, tetapi juga pada anak-anak dan remaja. Agar tubuh anak tetap sehat dan terhindar dari berbagai penyakit kronik atau penyakit tidak menular (PTM) terkait gizi maka pola makan perlu ditingkatkan ke arah konsumsi gizi seimbang. ${ }^{1}$

Persoalan yang cukup besar dan menjadi perhatian lebih yang dihadapi oleh seorang anak usia sekolah dasar (6-12 tahun) adalah keadaan gizi yang masih rendah. Berbagai studi di dunia menunjukkan bahwa hanya beberapa anak yang memenuhi rekomendasi asupan buah dan sayur per hari. Konsumsi makanan ringan yang tidak sehat, fast food, dan minuman ringan yang manis meningkat. ${ }^{2-4}$ Konsumsi buah dan sayur ratarata pada anak usia 5-14 tahun di Asia Tenggara menunjukkan hasil yang sangat rendah, yaitu 182 g/hari. ${ }^{5}$ Hasil Riset Kesehatan Dasar (Riskesdas) 2013 menunjukkan bahwa konsumsi sayur dan buah tiap hari merupakan cakupan paling rendah dari 10 indikator perilaku hidup bersih dan sehat (PHBS) yang hanya sebesar 10,7\%. ${ }^{6}$

Keluarga dapat dijadikan basis dalam strategi intervensi menanggulangi masalah kesehatan anak. Peranan ibu dalam keluarga yang masih mempunyai anak merupakan modal pokok untuk mewujudkan serta meningkatkan pemeliharaan kesehatan keluarga yang sehat dan sejahtera. Ibu sangat berperan pada perkembangan anak, salah satunya peranannya dalam menyediakan makanan yang bergizi. Oleh karena itu, penting bagi ibu mempunyai pengetahuan terkait nutrisi yang dibutuhkan oleh anak dengan konsumsi sayur dan buah serta aneka ragam makanan gizi seimbang lainnya dalam upaya pencegahan PTM pada anak..$^{7-9}$

Pemberdayaan pada masyarakat oleh bidan dapat dilaksanakan salah satunya dengan cara penyampaian informasi kepada ibu berkaitan dengan konsumsi aneka ragam makanan berbasis pedoman gizi yang seimbang pada anak ${ }^{10}$ sehingga dapatmeningkatkan pengetahuan terhadapupaya meningkatkan kewaspadaan masalah kesakitan atau kegawatdaruratan pada anak. Pemberian informasi tersebut harus memperhatikan media, materi atau pesan yang akan disampaikan, dan metode yang akan dipakai sehingga tercapailah hasil yang optimal. Media itu merupakan upaya untuk menampilkan informasi yang disampaikan sehingga pengetahuan sasaran dapat mengalami peningkatan dan mampu mengubah perilaku ke arah yang positif terhadap kesehatan. Alat bantu elektronik audiovisual adalah salah satu bentuk media pendidikan yang lebih baik bila dibanding dengan kata-kata dalam penyampaian informasi. Hasil penelitian itu memperlihatkan pemberian informasi menggunakan media audiovisual lebih baik daripada menggunakan media cetak. ${ }^{11}$

Berdasar atas data dari Riskesdas 2013 yang menyatakan bahwa 4 (empat) cakupan perilaku hidup bersih dan sehat (PHBS) terendah, yaitu mengonsumsi beraneka ragam makanan berbasis pedoman umum gizi yang seimbang, melakukan aktivitas fisik, mencuci tangan memakai sabun, serta juga menggosok gigi maka dibuatlah sebuah aplikasi berbasis android yang diberi nama Sayang ke Buah Hati (SEHATI). Aplikasi SEHATI mudah dilaksanakan oleh orang yang awam sehingga diharapkan mampu memudahkan para ibu untuk meningkatkan kesadaran, kebiasaan positif, dan pengetahuan akan upaya promotif serta preventif penyakit pada anak. Pada penelitian ini hanya meneliti terkait konsumsi aneka ragam makanan gizi seimbang pada anak sekolah dasar.

Tujuan penelitian ini menganalisis perbedaan asupan gizi anak dan pengetahuan ibu dalam menerapkan konsumsi beraneka ragam makanan gizi seimbang pada anak sekolah dasar sebelum dengan sesudah diterapkan aplikasi Sayang ke Buah Hati (SEHATI).

\section{Metode}

Penelitian ini menggunakan metode kuantitatif dengan desain penelitian randomized controlled trial (RCT). Subjek penelitian adalah ibu yang memiliki anak usia sekolah dasar (8-12 tahun) dan anaknya di SDIT Jabal Nur Yogyakarta sebanyak 60 orang. Peneliti memilih ibu yang memiliki anak usia tersebut karena pada usia tersebut siswa sudah mampu membaca dan juga menerima informasi dengan baik. Randomisasi sampel menggunakan cara undian, dari jumlah 60 sampel tersebut dibagi secara acak dan dikelompokkan menjadi dua kelompok, yaitu 30 orang diberikan aplikasi SEHATI dan 30 orang lainnya diberikan pendidikan kesehatan tentang konsumsi aneka ragam makanan gizi 

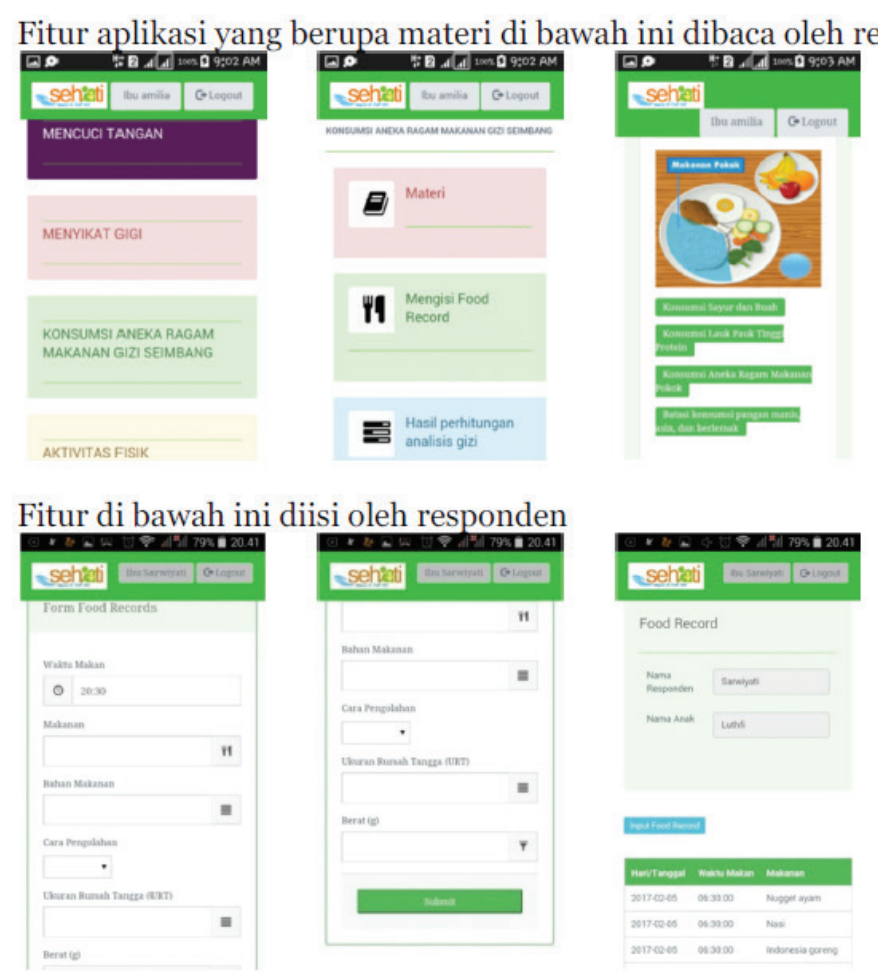

Fitur di bawah ini diisi oleh enumerator
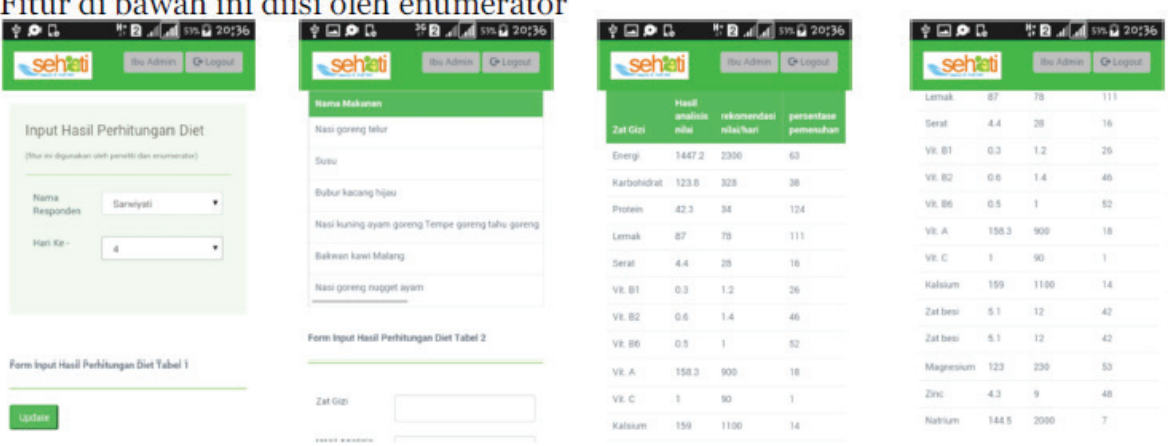

Gambar Fitur Aplikasi Sayang ke Buah Hati (SEHATI)

seimbang. Pengujian statistik mempergunakan uji t berpasangan pada data yang berdistribusi normal dan uji Mann-Whitney pada data yang tidak berdistribusi normal dengan kemaknaan hasil uji ditentukan berdasarkan nilai $\mathrm{p}<0,05$. Penelitian ini dilaksanakan selama dua minggu terhitung mulai tanggal 2-18 Maret 2017.

Pada kedua kelompok dilaksanakan pretes pengetahuan tentang pentingnya konsumsi aneka ragam makanan yang sesuai dengan pedoman gizi seimbang anak SD. Selanjutnya, responden dikumpulkan oleh peneliti untuk mendapatkan penjelasan dari enumerator (ahli gizi alumni Poltekkes Kemenkes Yogyakarta) terkait tata cara pengisian food record. Enumerator akan menjelaskan tentang pengisian food record dan bagaimana mengukur ukuran rumah tangga itu dengan menggunakan perangkat food model. Responden diminta menulis semua makanan dan minuman yang dikonsumsi oleh anak ke dalam food record (pretes) selama 3 hari, yaitu 2 hari kerja dan 1 hari libur.

Kelompok intervensi ibu yang mendapatkan aplikasi SEHATI dipasangkan oleh peneliti ke dalam smartphone milik responden, sedangkan pada kelompok kontrol diberikan pendidikan kesehatan selama 1 (satu) hari mempergunakan metode kelas dengan responden sebanyak 30 orang. Peneliti lalu menjelaskan materi terkait konsumsi aneka ragam makanan gizi seimbang 
berdasar atas buku Pedoman Gizi Seimbang dari Kementerian Kesehatan RI. Setelah penjelasan diberikan, peneliti membuka sesi diskusi pada responden dengan cara membagi menjadi lima kelompok. Tiap-tiap kelompok memperoleh satu kartu berisi submateri aneka ragam makanan gizi seimbang. Kelompok pertama mendapatkan kartu "konsumsi sayur", kelompok dua "konsumsi buah", kelompok tiga "konsumsi lauk pauk tinggi protein", pada kelompok empat "konsumsi aneka ragam makanan pokok", dan pada kelompok lima "pembatasan konsumsi pangan manis, asin, serta berlemak". Kemudian setiap kelompok diminta untuk menjelaskan submateri di dalam kartu tersebut. Sesi tanya jawab dilaksanakan setelah setiap kelompok selesai memberikan penjelasan. Tahap selanjutnya setelah dua minggu penelitian dilaksanakan, dilakukan penilaian pengetahuan ibu tentang konsumsi aneka ragam makanan sesuai pedoman umum gizi seimbang pada anak.

Penilaian asupan zat gizi anak dengan cara mencatat apa saja yang dikonsumsi anak pada tiga hari sebelum perlakuan dan enam hari (setiap minggu dinilai selama tiga hari tidak berurutan yang dilaksanakan selama dua minggu) setelah dipasang aplikasi SEHATI menggunakan metode food record. Zat gizi anak yang diukur asupannya terdiri atas zat gizi makro (karbohidrat, protein, dan lemak) dan zat gizi mikro (vitamin A, kalsium, zat besi, dan zinc).

Responden diminta mencatat semua makanan dan minuman yang telah dikonsumsi oleh anak sejak bangun tidur di pagi hari hingga menjelang tidur di malam hari selama 2 minggu (per minggu 3 hari maka totalnya 6 hari). Data yang terkumpul selanjutnya dikonversi ke dalam ukuran gram dengan acuan daftar bahan makanan penukar dan dianalisis mempergunakan program Nutrisurvey 2005. Nilai dari asupan zat gizi rata-rata yang diperoleh kemudian dibandingkan dengan angka kecukupan gizi (AKG) 2013 Indonesia. Hasil analisis gizi tersebut direkapitulasi. Responden mengisi food record di dalam aplikasi SEHATI pada kelompok intervensi, sedangkan untuk kelompok kontrol dapat melengkapi di lembaran formulir food record yang telah disediakan oleh peneliti.

Pada penelitian ini, angket diberikan kepada responden kelompok intervensi terkait sejauh mana aplikasi SEHATI itu dan materi konsumsi beraneka ragam makanan gizi yang seimbang ini bermanfaat. Keadaan ini dilakukan sebagai data penunjang. Angket diberikan pada akhir minggu penelitian.
Penelitian ini dilaksanakan di SDIT Jabal Nur Yogyakarta pada periode 2-18 Maret 2017 dan telah mendapatkan persetujuan dari Komisi Etik Penelitian Kesehatan Fakultas Kedokteran Universitas Padjadjaran dengan surat persetujuan etik Nomor: 51/UN6.C.10/PN/2017. Subjek yang digunakan telah memenuhi kriteria inklusi dan tidak termasuk kriteria eksklusi dengan jumlah sampel 60 orang ibu yang memiliki anak usia sekolah dasar (8-12 tahun) dan anaknya.

\section{Hasil}

Tabel 1 memperlihatkan bahwa sebagian besar responden pada kelompok intervensi dan kontrol berusia 30 tahun sampai dengan 39 tahun. Pendidikan terakhir responden terbanyak pada kedua kelompok adalah perguruan tinggi. Selain itu, responden terbanyak pada penelitian ini baik kelompok intervensi maupun kontrol adalah ibu dengan multipara yang telah memiliki anak lebih dari satu. Rata-rata responden adalah ibu yang memiliki pekerjaan dengan penghasilan keluarga terbanyak pada kelompok intervensi dan kontrol adalah $1-3$ juta rupiah.

Tabel 2 membandingkan nilai kebermaknaan secara statistik antara 2 (dua) kelompok setelah diberikan perlakuan. Terjadi peningkatan skor pengetahuan pada kedua kelompok. Peningkatan skor pada kelompok intervensi yang diterapkan aplikasi SEHATI yang bermakna secara statistik ( $\mathrm{p} \leq \mathrm{0}, \mathrm{001}$ ), sedangkan pada kelompok kontrol meskipun terjadi peningkatan skor, namun tidak bermakna secara statistik ( $\mathrm{p}=0,058)$.

Peningkatan zat gizi anak pada kelompok intervensi terjadi pada asupan energi, protein, karbohidrat, serat-serat, vitamin A, vitamin B6, vitamin $\mathrm{C}$, natrium, kalsium, magnesium, zat besi, dan zinc. Penurunan terjadi pada lemak, vitamin B1, dan juga vitamin B2. Dari lima belas zat gizi anak yang mengalami peningkatan sesudah intervensi, hanya enam zat gizi yang bermakna, yaitu serat $(p=0,001)$, vitamin A $(\mathrm{p}=0,001)$, vitamin $\mathrm{B} 6(\mathrm{p}=0,017)$, vitamin $\mathrm{C}$ ( $p=0,001)$, kalsium $(p=0,005)$, dan magnesium ( $\mathrm{p}=0,008)$, sedangkan pada kelompok kontrol yang mengalami peningkatan skor zat gizi adalah vitamin $\mathrm{B} 6(\mathrm{p}=0,001)$, vitamin $\mathrm{C}(\mathrm{p}=0,001)$, dan magnesium $(\mathrm{p}=0,024)$.

Tabel 3 untuk melihat berapa persen kenaikan sehingga dapat mengetahui seberapa besar pengaruh intervensi penerapan aplikasi SEHATI terhadap asupan zat gizi anak dan pengetahuan ibu menerapkan konsumsi aneka ragam makanan 
Tabel 1 Karakteristik Responden pada Kedua Kelompok Penelitian

\begin{tabular}{|c|c|c|c|}
\hline \multirow{2}{*}{ Karakteristik } & \multicolumn{2}{|c|}{ Kelompok } & \multirow{2}{*}{$\mathbf{p}$} \\
\hline & Intervensi $(n=30)$ & Kontrol $(n=30)$ & \\
\hline $\begin{array}{l}\text { Usia ibu (tahun) } \\
\text { 30-39 } \\
40-49\end{array}$ & $\begin{array}{c}23 \\
7\end{array}$ & $\begin{array}{c}26 \\
4\end{array}$ & 0,677 \\
\hline $\begin{array}{l}\text { Pendidikan ibu } \\
\text { Menengah (SMP, SMA) } \\
\text { Tinggi (PT) }\end{array}$ & $\begin{array}{c}5 \\
25\end{array}$ & $\begin{array}{c}5 \\
25\end{array}$ & 0,627 \\
\hline $\begin{array}{l}\text { Paritas ibu } \\
\text { Primipara } \\
\text { Multipara }\end{array}$ & $\begin{array}{c}4 \\
26\end{array}$ & $\begin{array}{c}3 \\
27\end{array}$ & 0,640 \\
\hline $\begin{array}{l}\text { Pekerjaan ibu } \\
\text { Bekerja } \\
\text { Tidak bekerja }\end{array}$ & $\begin{array}{c}24 \\
6\end{array}$ & $\begin{array}{c}26 \\
4\end{array}$ & 0,169 \\
\hline $\begin{array}{l}\text { Penghasilan keluarga (rupi } \\
1-3 \text { juta } \\
>3 \text { juta }\end{array}$ & $\begin{array}{c}26 \\
4\end{array}$ & $\begin{array}{c}24 \\
6\end{array}$ & 0,604 \\
\hline
\end{tabular}

Keterangan: berdasar atas uji chi-square

Tabel 2 Perbandingan Skor Asupan Gizi Anak dan Pengetahuan Ibu Menerapkan Konsumsi Aneka Ragam Makanan Gizi Seimbang pada Anak Sekolah Dasar Kelompok Intervensi dan Kelompok Kontrol

\begin{tabular}{|c|c|c|c|c|c|c|}
\hline \multirow{2}{*}{$\begin{array}{l}\text { Variabel } \\
\text { (Skala 10o) }\end{array}$} & \multicolumn{2}{|c|}{ Intervensi $(n=30)$} & \multirow[t]{2}{*}{$\mathbf{p}$} & \multicolumn{2}{|c|}{ Kontrol $(n=30)$} & \multirow{2}{*}{$\mathbf{p}$} \\
\hline & Pretes & Postes & & Pretes & Postes & \\
\hline $\begin{array}{l}\text { Skor pengetahuan } \\
\text { Median } \\
\text { Rentang }\end{array}$ & $\begin{array}{c}78,9 \\
36,8-94,7\end{array}$ & $\begin{array}{c}89,5 \\
84,2-94,7\end{array}$ & $<0,001^{* *}$ & $\begin{array}{c}73,7 \\
21,1-89,5\end{array}$ & $\begin{array}{c}73,7 \\
31,6-89,5\end{array}$ & $0,058^{* *}$ \\
\hline $\begin{array}{l}\text { Skor asupan zat giz } \\
\text { anak } \\
\text { Energi (kcal) }\end{array}$ & & & & & & \\
\hline $\begin{array}{l}\text { Rata-rata (SD) } \\
\text { Rentang }\end{array}$ & $\begin{array}{c}1.370,1(252,6) \\
865,7-1.824,5\end{array}$ & $\begin{array}{c}1.425,5(232,7) \\
1.035,1-1.942,6\end{array}$ & 0,291 & $\begin{array}{l}1.411,8(224,6) \\
990,4-1.889,3\end{array}$ & $\begin{array}{c}1.440,1(212,1) \\
991,5^{-1.774,8}\end{array}$ & $0,479^{*}$ \\
\hline $\begin{array}{l}\text { Protein (g) } \\
\text { Rata-rata (SD) } \\
\text { Rentang }\end{array}$ & $\begin{array}{l}50,4(11,9) \\
26,4-70,6\end{array}$ & $\begin{array}{l}51,2(10,1) \\
28,2-79,5\end{array}$ & $0,729^{*}$ & $\begin{array}{l}51,5(10,6) \\
29-77,4\end{array}$ & $\begin{array}{l}55,4(12,2) \\
29,5-76,3\end{array}$ & $0,057^{*}$ \\
\hline $\begin{array}{l}\text { Lemak (\% energi } \\
\text { total) } \\
\text { Rata-rata (SD) } \\
\text { Rentang }\end{array}$ & $\begin{array}{l}51,9(15,2) \\
29,7-94,2\end{array}$ & $\begin{array}{l}50,5(11,3) \\
35,2-81,9\end{array}$ & $0,640^{*}$ & $\begin{array}{l}54,3(12,9) \\
32,4-83,1\end{array}$ & $\begin{array}{l}56,0(12,6) \\
34,5^{-76,9}\end{array}$ & $0,440^{*}$ \\
\hline $\begin{array}{l}\text { Karbohidrat (\% } \\
\text { energi total) } \\
\text { Rata-rata (SD) } \\
\text { Rentang }\end{array}$ & $\begin{array}{r}175,0(36,6) \\
103,4-249,6\end{array}$ & $\begin{array}{c}193,4(33,5) \\
120,9-274,6\end{array}$ & $0,16^{*}$ & $\begin{array}{c}178(30,2) \\
117,7-242,5\end{array}$ & $\begin{array}{c}178,8(24) \\
122,6-237,6\end{array}$ & $0,897^{*}$ \\
\hline $\begin{array}{l}\text { Vit. A (mcg) } \\
\text { Rata-rata (SD) } \\
\text { Rentang }\end{array}$ & $\begin{array}{c}572,6(206,5) \\
227,8-918,4\end{array}$ & $\begin{array}{l}760,1(224,4) \\
375,4-1.332,1\end{array}$ & $0,001^{*}$ & $\begin{array}{c}569,6(181,2) \\
256,3-1.089,1\end{array}$ & $\begin{array}{l}532,7(131,8) \\
279,2-825,1\end{array}$ & $0,385^{*}$ \\
\hline $\begin{array}{l}\text { Kalsium (mg) } \\
\text { Rata-rata (SD) } \\
\text { Rentang }\end{array}$ & $\begin{array}{c}273,70(106,72) \\
118,9-544,8\end{array}$ & $\begin{array}{c}330,48(121,13) \\
116,8-586,9\end{array}$ & $0,005^{*}$ & $\begin{array}{c}236,24(101,8) \\
86,8-492,3\end{array}$ & $\begin{array}{c}276,33(65,37) \\
137,5^{-420,4}\end{array}$ & $0,086^{*}$ \\
\hline $\begin{array}{l}\text { Zat besi (mg) } \\
\text { Rata-rata (SD) } \\
\text { Rentang }\end{array}$ & $\begin{array}{c}6,47(1,97) \\
2,6-10,9\end{array}$ & $\begin{array}{c}7,02(1,99) \\
2,6-10,7\end{array}$ & $0,104^{*}$ & $\begin{array}{c}6,38(1,59) \\
4,3-10,3\end{array}$ & $\begin{array}{l}6,8(1,57) \\
4,6-10,2\end{array}$ & $0,158^{*}$ \\
\hline $\begin{array}{l}\text { Zinc (mg) } \\
\text { Rata-rata (SD) } \\
\text { Rentang }\end{array}$ & $\begin{array}{c}5,47(1,30) \\
3,2-7,9\end{array}$ & $\begin{array}{c}5,53(0,86) \\
3,9-7,8\end{array}$ & $0,788^{*}$ & $\begin{array}{c}5,55(1,2) \\
3,4-8\end{array}$ & $\begin{array}{c}5,86(1,09) \\
4-8,3\end{array}$ & $0,195^{*}$ \\
\hline
\end{tabular}


\begin{tabular}{l} 
Tabel $3 \begin{array}{l}\text { Analisis Persen Kenaikan Asupan Gizi Anak dan Pengetahuan Ibu Menerapkan } \\
\text { Konsumsi Aneka Ragam Makanan Gizi Seimbang pada Anak Sekolah Dasar } \\
\text { Kelompok Intervensi dan Kelompok Kontrol }\end{array}$ \\
\hline
\end{tabular}

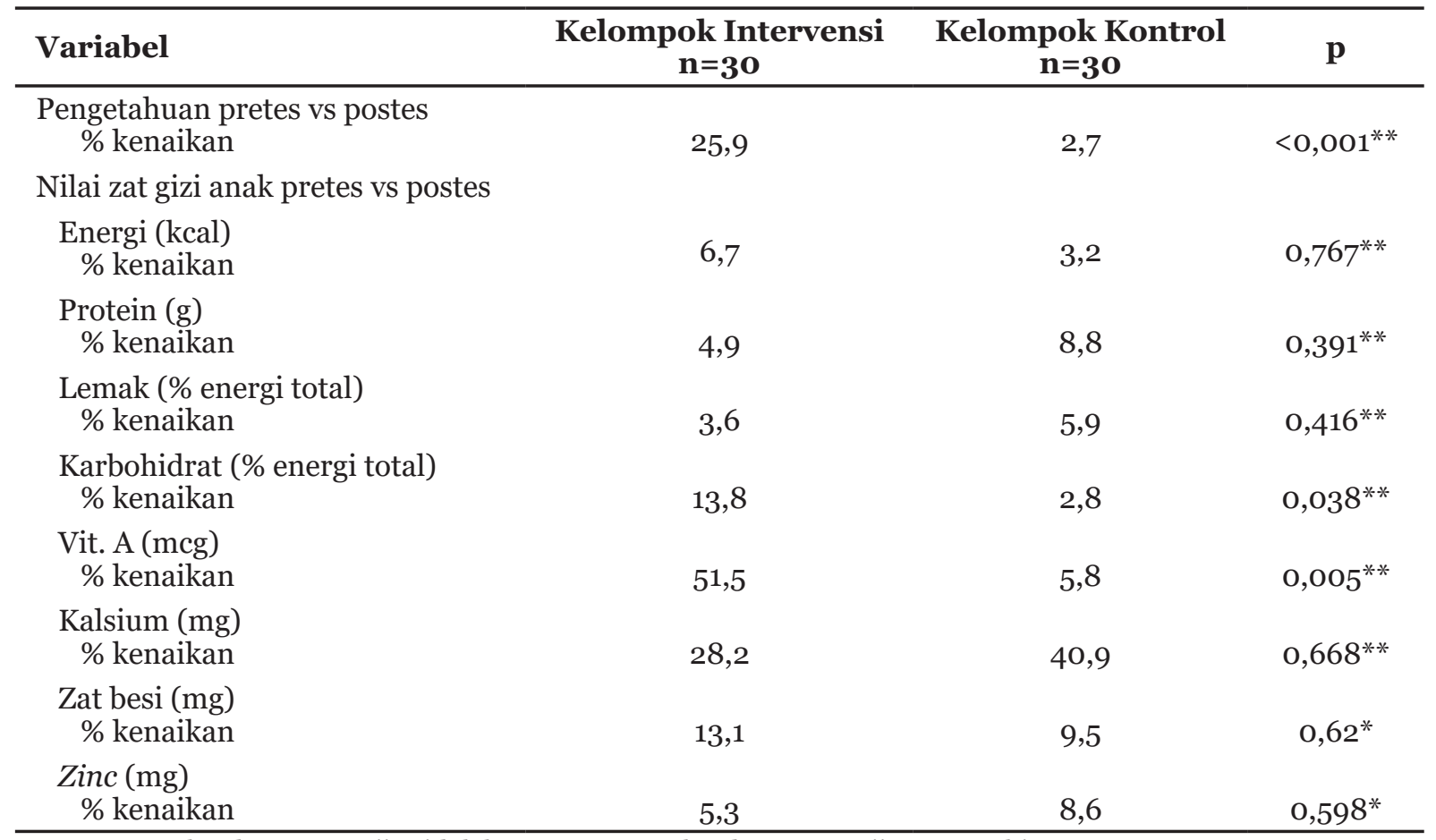

Keterangan: *berdasar atas uji t tidak berpasangan, ${ }^{* *}$ berdasar atas uji Mann-Whitney

gizi seimbang pada anak sekolah dasar dibanding dengan kelompok kontrol. Persentase kenaikan pengetahuan setelah diberi perlakuan aplikasi
SEHATI yang berbeda bermakna ( $\mathrm{p} \leq \mathrm{0}, \mathrm{oo1})$. Pada variabel asupan zat gizi anak, skor zat gizi dengan persen kenaikan bermakna pada kelompok yang

\section{Tabel 4 Penggunaan Aplikasi SEHATI}

\begin{tabular}{lc}
\hline Pertanyaan & Intervensi (Aplikasi SEHATI) \\
\hline Frekuensi membaca materi & 17 \\
$2-3$ kali/hari & 13 \\
$>3$ kali/hari & \\
Sumber informasi sebelumnya & 10 \\
4 sumber & 15 \\
3 sumber & 5 \\
2 sumber & \\
$\quad$ sumber: buku, media massa, media elektronik, internet) & 27 \\
Kesesuaian hasil dengan keinginan/kebutuhan & 3 \\
Ya & \\
Tidak & 18 \\
Kemudahan penggunaan & 6 \\
Tanpa bantuan & 6 \\
Sedikit bantuan & \\
Beberapa kurang dimengerti & 10 \\
Kemudahan membaca hasil analisis gizi & 20 \\
Tanpa bantuan & \\
Dengan bantuan & \\
\hline
\end{tabular}


diberi intervensi adalah karbohidrat, vitamin A, dan vitamin B6.

Tabel 4 memperlihatkan bahwa responden pada kelompok intervensi membuka aplikasi SEHATI dan membaca materi konsumsi aneka ragam makanan sesuai gizi seimbang dengan frekuensi terbanyak 2-3 kali/hari. Responden yang sebelumnya pernah membaca materi ini dari buku, media massa, internet, dan media elektronik, frekuensi paling banyak adalah ibu yang membaca dari 3 sumber. Sebagian besar responden mengemukakan bahwa aplikasi ini memiliki hasil yang sesuai dengan keinginan/ kebutuhan mereka. Sepertiga responden dapat dengan mudah mempergunakan aplikasi ini tanpa bantuan, sedangkan sisanya memerlukan bantuan.

\section{Pembahasan}

Aplikasi Sayang ke Buah Hati ini memuat empat materi pokok terkait empat cakupan terendah perilaku hidup bersih dan sehat (PHBS) menurut Riskesdas tahun 2013. Empat materi pokok tersebut adalah konsumsi aneka ragam makanan gizi seimbang, melakukan aktivitas fisik, mencuci tangan memakai sabun, dan menggosok gigi yang benar. Pada pokok bahasan konsumsi aneka ragam makanan gizi seimbang, termuat materi yang diambil dari buku Pedoman Gizi Seimbang dan analisis perhitungan matematis kebutuhan gizi anak per harinya yang terdiri atas zat gizi makro (karbohidrat, protein, dan lemak) dan zat gizi mikro (vitamin $\mathrm{A}$, kalsium, zat besi, dan zinc) dengan acuan daftar bahan makanan penukar yang kemudian dibandingkan dengan AKG 2013 Indonesia, sedangkan pokok bahasan melakukan aktivitas fisik, mencuci tangan memakai sabun, dan menggosok gigi yang benar memuat materi edukasi. Selain memuat materi edukasi dan analisis matematis kebutuhan gizi anak per hari, aplikasi SEHATI turut memuat reminder yang ditujukan bagi para pengguna untuk senantiasa menulis apa yang anak makan sejak bangun tidur di pagi hari hingga menjelang tidur di malam hari. Animasi bergerak dan bahasa yang mudah dipahami dapat menjadi salah satu nilai lebih pada aplikasi SEHATI ini.

Aplikasi SEHATI segera dapat dipergunakan sesudah responden pada kelompok intervensi melaksanakan registrasi dengan cara menulis data diri lengkap ibu dan anak pada form yang terdapat dalam aplikasi SEHATI. Kemudian responden mengisi kuesioner pada salah satu pokok bahasan. Dalam penelitian ini responden mengisi kuesioner pada pembahasan konsumsi aneka ragam makanan gizi seimbang. Setelah melengkapi kuesioner maka responden sudah dapat log in dan mengakses materi dalam aplikasi SEHATI.

Pengetahuan ibu tentang konsumsi beraneka ragam makanan sesuai gizi seimbang pada anak harus diberikan terhadap masyarakat luas tidak terbatas pada kelompok tertentu. Diharapkan dengan mengetahui informasi beraneka ragam makanan yang sesuai gizi seimbang pada anak, orangtua khususnya ibu dapat menyadari bahwa konsumsi pangan penting untuk pertumbuhan dan perkembangan anak.

Terjadi peningkatan pada skor pengetahuan yang bermakna dalam kelompok intervensi sebesar $25,9 \%$ bila dibanding dengan kelompok kontrol 2,7\% dengan nilai $\mathrm{p}=0,001$ (Tabel 3). Responden yang membaca materi di aplikasi SEHATI dengan frekuensi $2-3 \mathrm{kali} / \mathrm{hari}$ dapat membantu meningkatkan pengetahuan sampai 25,9\%. Terjadi pula peningkatan skor asupan zat gizi anak pada kelompok intervensi yang bermakna, yaitu karbohidrat $(13,8 \%$; $\mathrm{p}=0,038)$ dan vitamin A (51,5\%; $\mathrm{p}=0,005)$. Hal tersebut ditunjang juga dengan responden yang pernah memperoleh informasi sebelumnya dari tiga sumber, yaitu media massa, media elektronik, dan internet. Lebih dari setengah responden kelompok intervensi menyatakan bahwa aplikasi SEHATI mudah digunakan serta materi dan fitur dalam aplikasi ini sesuai dengan keinginan atau kebutuhan (Tabel 4).

Media merupakan salah satu faktor penentu keberhasilan pembelajaran atau penyampaian informasi. Penggunaan media dapat membantu untuk memperjelas pesan pembelajaran. Sejalan dengan hasil penelitian ini, sebuah penelitian menyatakan bahwa manusia itu lebih mudah dan cepat untuk mempelajari suatu hal dengan proses audiovisual bila dibanding dengan hanya penjelasan. Materi audiovisual efektif digunakan dan mempunyai berbagai keuntungan. Media audiovisual sangat berkontribusi meningkatkan pengetahuan seseorang untuk dapat menangkap suatu informasi, di antaranya $40 \%$ informasi diperoleh dengan pengalaman visual dan $25 \%$ pendengaran. ${ }^{11,12}$ Penelitian lainnya menyatakan bahwa penggunaan alat bantu guna meningkatkan partisipasi masyarakat dalam sebuah program ternyata sudah terbukti berhasil dalam beberapa program, salah satunya terkait edukasi dan juga pemantauan kesehatan masyarakat. ${ }^{13}$ 
Penting bagi ibu untuk memahami dengan benar terkait kandungan zat gizi makanan dan pengaruh zat gizi tersebut terhadap kesehatan anaknya sehingga dapat membentuk karakter perilaku hidup sehat. ${ }^{14}$ Anak usia sekolah dasar umumnya memiliki kegiatan yang lebih aktif sehingga kebutuhan zat gizinya harus tercukupi dengan seimbang, artinya nilai gizinya harus sesuai dengan kebutuhan berdasar atas usia dan jenis bahan makanan seperti karbohidrat, protein, dan lemak. ${ }^{15}$

Hasil analisis kebutuhan zat gizi anak per hari dapat dilihat pada fitur di dalam aplikasi SEHATI. Lebih dari $80 \%$ responden menyatakan bahwa sulit membaca hasil analisis zat gizi sehingga membutuhkan bantuan peneliti. Hal ini dapat terjadi karena format hasil analisis zat gizi sama dengan program komputer Nutrisurvey yang kurang dapat dipahami masyarakat awam. Hal ini merupakan kelemahan dari aplikasi SEHATI yang akan diperbarui untuk perbaikan aplikasi selanjutnya.

Asupan makananyang bergiziguna menunjang masa pertumbuhan dan perkembangan sangat dibutuhkan pada fase anak usia sekolah dasar. Kebutuhan tubuh terhadap energijauh lebih besar bila dibanding dengan usia sebelumnya karena anak sekolah lebih banyak melakukan aktivitas fisik seperti bermain atau berolahraga. Beberapa hal yang memengaruhi asupan zat gizi anak adalah peranan ibu yang menyediakan makanan itu di rumah. ${ }^{16}$ Meskipun terdapat peningkatan pengetahuan ibu secara bermakna pada kelompok intervensi, namun pada penerapannya ibu agak susah mengubah kebiasaan mempersiapkan konsumsi pangan pada anak.

Pada era modern ini ibu cenderung memilih makanan yang praktis seperti junk food dan fast food yang kandungan lemaknya tinggi.3.4 Hal tersebut dilakukan oleh sebagian besar ibu karena preferensi makanan pada anak. Selain itu, kehadiran teman sebaya dan lingkungan pun memengaruhi perilaku anak yang tidak menyukai mengonsumsi aneka ragam makanan sesuai dengan gizi seimbang. ${ }^{3}$ Ketersediaan sayur dan buah serta penghasilan orangtua dalam hal ini adalah ibu juga turut menjadi faktor yang mengakibatkan kesulitan mengubah kebiasaan ibu menerapkan konsumsi aneka ragam makanan sesuai gizi seimbang untuk meningkatkan asupan zat gizi anaknya, meskipun ibu membaca materi dengan frekuensi $>3 \mathrm{kali} / \mathrm{hari}$ dan berasal dari 3 sumber informasi sebelumnya. Hal tersebut sejalan dengan sebuah studi yang dilakukan di Australia. ${ }^{17}$

\section{Simpulan}

Terdapat perbedaan peningkatan pengetahuan ibu menerapkan konsumsi aneka ragam makanan gizi seimbang pada anak sekolah dasar sebelum dengan sesudah penggunaan aplikasi Sayang ke Buah Hati (SEHATI). Terdapat perbedaan peningkatan asupan zat gizi anak sebelum dengan sesudah penggunaan aplikasi SEHATI. Terjadi peningkatan skor zat gizi anak (karbohidrat dan vitamin $\mathrm{A}$ ) pada kelompok intervensi

\section{Daftar Pustaka}

1. Kementerian Kesehatan RI. Pedoman gizi seimbang. Jakarta: Kemenkes RI; 2014.

2. Lin W, Yang HC, Hang CM, Pan WH. Nutrition knowledge, attitude, and behavior of Taiwanese elementary school children. Asia Pac J Clin Nutr. 2007;16(Suppl 2):534-46.

3. Waddingham S, Stevens S, Macintyre K, Shaw K. Most of them are junk food but we did put fruit on there and we have water: what children can tell us about the food choices they make. Health Educ. 2015;115(2):126140.

4. Kunin-Batson AS, Seburg EM, Crain AL, Jaka MM, Langer SL, Levy RL, dkk. Household factors, family behavior patterns, and adherence to dietary and physical activity guidelines among children at risk for obesity. J Nutr Educ Behav. 2015;47(3):206-15.

5. Upton D, Upton P, Taylor C. Fruit and vegetable intake of primary school children: a study of school meals. J Hum Nutr Diet. 2012;25(6):557-62.

6. Badan Penelitian dan Pengembangan Kesehatan, Kementerian Kesehatan RI. Riset kesehatan dasar (Riskesdas) 2013. Jakarta: Badan Litbangkes, Kemenkes RI; 2013.

7. Saldiva SRDM, Venancio SI, de Santana AC, da Silva Castro AL, Escuder MML, Giugliani ERJ. The consumption of unhealthy foods by Brazilian children is influenced by their mother's educational level. Nutr J. 2014;13:33.

8. Davis J, Pickering AJ, Rogers K, Mamuya S, Boehm AB. The effects of informational interventions on household water management, hygiene behaviors, 
stored drinking water quality, and hand contamination in peri-urban Tanzania. Am J Trop Med Hyg. 2011;84(2):184-91.

9. Al-Shookri A, Al-Shukaily L, Hassan F, Al-Sheraji S, Al-Tobi S. Effect of mothers nutritional knowledge and attitudes on Omani children's dietary intake. Oman Med J. 2011;26(4):253-7.

10. Kementerian Kesehatan RI. Promosi kesehatan di daerah bermasalah kesehatan: panduan bagi petugas kesehatan di puskesmas. Jakarta: Kemenkes RI; 2011.

11. Ashaver D, Igyuve SM. The use of audiovisual materials in the teaching and learning processes in colleges of education in Benue State-Nigeria. IOSR-JRME. 2013;1(6):4455 .

12. Seçer SYE, Şahin M, Alci B. Investigating the effect of audio visual materials as warmup activity in Aviation English courses on students' motivation and participation at high school level. Procedia Soc Behav Sci. 2015;199:120-8.

13. Respati T, Nurhayati E, Mahmudah,
Feriandi Y, Budiman, Yulianto F, dkk. Pemanfaatan kalender 4M sebagai alat bantu meningkatkan peran serta masyarakat dalam pemberantasan dan pencegahan demam berdarah. GMHC. 2016;4(2):121-7.

14. Nuryanto, Pramono A, Puruhita N, Muis SF. Pengaruh pendidikan gizi terhadap pengetahuan dan perilaku konsumsi serat pada siswa. JGI. 2014;3(1):32-6.

15. Nicklas TA, Hayes D; American Dietetic Association. Position of the American Dietetic Association: nutrition guidance for healthy children ages 2 to 11 years. J Am Diet Assoc. 2008;108(6):1038-44, 1046-7.

16. Yabancı N, Kısaç İ, Karakuş SŞ. The effects of mother's nutritional knowledge on attitudes and behaviors of children about nutrition. Procedia Soc Behav Sci. 2014;116:4477-81.

17. Campbell KJ, Abbott G, Spence AC, Crawford DA, McNaughton SA, Ball K. Home food availability mediates associations between mothers' nutrition knowledge and child diet. Appetite. 2013;71:1-6. 